\title{
Economic Evaluation of Investments in Airports: Recent Developments
}

Peter Forsyth

Department of Economics, Monash University, Clayton, 3800

peter.forsyth@buseco.monash.edu.au

Hans-Martin Niemeier

University of Applied Sciences, Werderstr. 73, D 28199 Bremen / Germany

P: +49-40-8119377 F +49-421-5905-4815

Hans-Martin.Niemeier@hs-bremen.de

Eric Tchouamou Njoya

University of Huddersfield, Queensgate Huddersfield, HD1 3DH e.njoya@ @ud.ac.uk

\begin{abstract}
The problem of how to evaluate investments in airports has now been studied for over fifty years. This paper analyses the use of different methods like Cost Benefit Analysis (CBA), Economic Impact Analysis (EIA) and Computable General Equilibrium (CGE) models to address the question. It assesses the strength and weaknesses of each method, and it discusses which methods have been used in different countries.

The paper argues that the CBA approach, and the newer CGE modelling approach address the policy issue well and that both methods are appropriate, although improvements are possible, especially in the newer aspects of evaluation. Furthermore, more data intensive CGE models are able to analyse broader aspects of the evaluation question for which CBA has had difficulty. EIA does not address the problem satisfactorily and it misleads air transport policy. But this evaluation contrasts sharply with practice. EIA has been extensively used to decide on airport investment. CGE approaches are very promising, though further work is needed for them to reach their full potential. This paper pays particular attention to the relationship between CBA and CGE in airport investment evaluation, and also the possible role of wider economic benefits (WEBs) of aviation in evaluation.
\end{abstract}

Key Words: Airport investment, Cost Benefit Analysis, Economic Impact Analysis, and Computable General Equilibrium models; Wider Economic Benefits of Aviation 
"At least in some instances, impact studies will be employed, explicitly or implicitly, deliberately or unintentionally, as justification for adopting a specific course of action. Analysts may wish their hands of any blame for the subsequent misuse or misinterpretation of the findings of an impact study. No professional error has been committed on their part. But this does raise the moral conundrum of whether or not an analyst might be guilty of a professional "sin" of omission."

W. G. Waters (1976)

\section{Introduction}

The continuous growth of air transport has led to a situation that, in many countries, demand exceeds airport capacity. Expanding airport capacity in large urban areas has proven to be difficult. Airports are very land intensive, and they are the source of negative externalities, such as noise, local traffic and local emissions. While the positive effects, in the form of better connectivity and additional production and income, are distributed in the wider region of the airport, the negative effects are borne by the local neighbours. This has led to long lasting public planning processes with often still unresolved conflicts, and the legitimacy and rationality of these planning processes have often been criticised. Rural areas often see good air transport connections to centres as being vital for promoting growth and tourism. However, while many airports can be justified in terms of territorial accessibility, many airports have been built where there is no lack of capacity. There is evidence that airports have extended runways for intercontinental flights which have never materialized. There is also evidence of "white elephant" airports such as the airport of Kassel-Calden (Germany) and Don Quixote Airport (Spain). Getting the investment decision right is very often as challenging as important for urban and rural regions. This raises the question of how airport investment be best evaluated? There is no single way in which airport investments are assessed - there are several techniques of assessment, and these differ widely in terms of their implications. Thus there is a problem of how best to evaluate investments, whether they are for small changes or major new airports. ${ }^{1}$

There are several techniques which have been used in evaluating airport investments- we focus our attention on three, which are probably the most widely used ones. These are Cost Benefit Analysis (CBA), Economic Impact Analysis (EIA) models and Computable General Equilibrium (CGE) models. There have been other techniques of evaluation which have been suggested - one of these is Multi Criteria Analysis (Quinet, 2000). As the name suggests, thus it is a means of taking a broader set of aspects into account than is common with CBA. Another technique is that of Strategic Environmental Assessment (Partidario and Miguel, 2011), which has been used to evaluate airport choices in Portugal. In the past, this question was answered by recommending (CBA). More recently, other techniques have been used. There has been a

\footnotetext{
${ }^{1}$ While this paper is focussed on airports, it should be noted that many of the issues are relevant to other transport evaluations, such as those for road and rail investments.
} 
strong growth in the use of EIA models. While popular among proponents, EIA models have fundamental flaws, which render them inappropriate for investment evaluation. More recently, there has been the use of CGE models in airport evaluation.

Boardman et al. (2017, p. 2) define CBA as a 'policy method that quantifies in monetary terms the values of all consequences of a policy to all member of the society'. EIA models estimate how a project or policy affects the level of economic activity in a given area. CGE models may be defined as a system of equations that represent the economy, taking into account the interdependence between industries, as well as the interaction between the agents in the economy. It is important to note that EIA is not the same as CBA and that EIA, while having some similarities to CGE models, differ due to their underlying assumptions. Economic impact analysis focuses on measurable changes in jobs, output and earnings. This is different from CBA, which estimates the equivalent monetary value of the costs and benefits to the society of a project or policy. CGE models are based on both micro- and macroeconomic theoretical foundations and unlike EIA, the impact of prices on decisions is crucial in a CGE model. Furthermore, the economy in a CGE model operates under technological and institutional constraints. Some CGE models can quantify all consequences of a policy, including welfare effects, in the manner of CBA.

CGE models are rigorous and appropriate for the task. At present, these models have only recently been applied to the airport evaluation task, and there are several questions concerning how best to use them. However, as techniques improve, they are a promising development.

This paper seeks to explore several aspects of the airport evaluation issue:

- Firstly, we examine the nature of the evaluation problem for airports, drawing attention to several key problems;

- Next, we look at the history and current use of the different techniques as used in a range of countries;

- Then we recognise the old problems, such as those of noise and value of time, and pay particular attention to newer problems, such as connectivity and tourism benefits, and the possible existence of wider economic benefits (WEBs);

- After which, the three techniques- CBA, EIA and CGE are evaluated, and the positives and negatives of the three are discussed critically.

- And finally, we discuss how CBA and CGE approaches can be improved to make full use of their potential.

The results provide a current road map to airport investment evaluation.

In exploring these questions, two new significant issues emerge. The first concerns the relationship between CBA and CGE - how different are these, especially in well-functioning market economies? Will CBA be superseded by CGE? The second concerns a new aspect of benefits, specifically, WEBs. What is the progress on measuring these benefits in the aviation context, and how large are they likely to be? In what ways are they comparable to catalytic effects, a new aspect from the EIA literature? 
We acknowledge that the deficiencies of EIA have been well recognised in the past. However, we do discuss the technique for at least two reasons. Firstly, EIA continues to be used very often in airport evaluation, and any survey of approaches needs to take it into account. Secondly, we wish to discuss the relationship of wider economic benefits, which is discussed in the CBA, and now CGE context, and the growing references to catalytic benefits, which stem from the EIA literature.

Airport investments can have a range of impacts within the region in which they are located. Measuring and evaluating these can be difficult and controversial. In this paper we do not go into these broader regional policy aspects of airports (though we note that catalytic effects, discussed in section 4.2.2, are often an attempt to address these).

In section 2, we provide an overview of the key aspects of investment evaluation as it applies to airports. We then look at the main old and new issues for evaluation, and then the three main techniques of evaluation - we note the history of their use, and discuss some of the main issues to do with their use, paying particular attention to the relationship of CBA to CGE, and to WEBs. In section 5 we summarise the findings and discuss these techniques in perspective.

\section{The Evaluation Task for Airport Investment}

\subsection{The Three Techniques}

There are several techniques which have been used in evaluating airport investments- we focus our attention on three, which are probably the most widely used ones. These are CBA, EIA and CGE.

Fundamentally, the evaluation task requires the welfare question to be answered- will the economy be better or worse off as a result of the investment? Of the three techniques:

- CBA answers this question;

- CGE can answer it, as long as there is a welfare measure embodied in the model; and

- EIA cannot answer it.

The first of these is not surprising. CBA was developed specifically to answer this question, and it is recognised as being successful in doing so, though of course, there are always limitations. CGE models often, but not always, are able to answer the question when they include a (properly derived) welfare measure.

By contrast, EIA cannot answer the question. As mentioned above, EIA makes an estimate of several of the impacts of the investment- its impact on output, its impact on employment, and so forth. However, it does not measure the impact on welfare or the benefits and costs of the investment. While users of EIA very often state that they are measuring the "benefits" of the investment, they are using the term quite differently from the normal welfare economics sense. Thus EIA cannot provide a rigorous measure of the welfare effects of the investment - i.e., assess whether the economy is better off as a result of the investment. 
CBA and CGE can provide an answer to the central question of whether the country gains from the investment. However, there are further issues to do with the impacts of the investmentthese might be to do with the impact on GDP, employment or other variables of interest. These may be of interest to the decision makers, even though they may not be of primary interest to the economist making the evaluation. CBA is not of great use here- it focusses on the welfare question alone. The other techniques appear to cast light on these further issues- for example, a CGE model or an EIA will provide estimates of the impact on non-welfare aspects, such as the impact on GDP or on employment.

There is, however, a large difference between the outputs of a CGE analysis and those of an EIA. Properly done, a CGE model provides a rigorous assessment of impacts. This is not the case with an EIA - these are discussed below. EIA makes an exaggerated estimate of the effect on output and employment since it assumes that the resources to make the investment are costless. A CGE approach is the only reliable means of estimating the broader impacts of the investment.

\subsection{Benefits and Impacts}

There is widespread confusion about the terms "impacts" and "benefits", especially in the EIA literature. The term "impact" is also increasingly being used in the CBA literature. However, it is important to emphasise that impact should not be used beyond EIA and CGE. Impacts and benefits are not the same (see Waters, 1976). By benefits, we mean the monetised value of benefits, as used in CBA, or in welfare economics generally. Welfare rises if benefits increase, ceteris paribus. These can be compared to costs, and the usual investment criterion is that benefits exceed costs. "Impacts" is a much broader term. There can be positive or negative impacts of an investment on many variables, such as employment, industry output, GDP, GNP, interest rates and national consumption- some of these may increase welfare, and others may not. Two possible impacts could be on benefits or costs. In recent years, the terms WEBs and also wider economic impacts (WEIs) have been used in the transport economics literature- in keeping with the terminology above, we understand WEIs to include impacts such as those on GDP and employment.

CBA seeks to measure benefits and costs, and determine whether a policy or investment increases net social benefits (NSB) or welfare. Models which seek to measure impacts may or may not be capable of measuring welfare. EIAs are not capable of doing this, and CGE models can only measure it if they have a welfare component included. Thus, in evaluating investments, only CBA and some CGE models can measure whether the nation is better off as a result of the investment (see Table 1).

Table 1: Evaluation of Impacts and Benefits

\begin{tabular}{lll}
\hline Technique & $\begin{array}{l}\text { Evaluating } \\
\text { Impacts }\end{array}$ & \begin{tabular}{l} 
Evaluating $\begin{array}{c}\text { Trade-offs } \\
\text { between Benefits and Costs }\end{array}$ \\
\hline Cost Benefit Analysis
\end{tabular} \\
\hline
\end{tabular}




\begin{tabular}{|c|c|c|}
\hline Economic Impact Analysis & $\begin{array}{l}\text { Yes } \\
\text { (Inaccurately) }\end{array}$ & No \\
\hline $\begin{array}{l}\text { Computable General Equilibrium } \\
\text { Models (Without Welfare Measure) }\end{array}$ & Yes & No \\
\hline $\begin{array}{l}\text { Computable General Equilibrium } \\
\text { Models (With Welfare Measure) }\end{array}$ & Yes & Yes \\
\hline
\end{tabular}

\section{Key Problems for Airport Evaluation}

In this section, we analyse the key problem areas which need to be addressed when using the techniques. It is useful to note that these problems are not the same for the three techniques. Many of the CBA issues are very relevant in the case of CGE models. Not all of these problem areas are addressed with specific techniques - EIA in particular does not address several of these. EIA models have different issues, such as the estimation of catalytic effects.

\subsection{Major Issues for Evaluation}

We set out the major issues that a good airport evaluation study should address, drawing on examples of our findings.

It is useful to make a distinction between issues which have been recognised for many decades (traditional issues) and those which have only recently been given much attention (new issues). Some of the traditional issues (see below table) are:

- Noise and externalities;

- Distribution of benefits and costs;

- The value of time;

- Airport pricing and congestion;

- Unemployment, and

- Land Use

Some new issues are:

- Tourism benefits;

- Climate change externalities; and

- Wider Economic Benefits, Connectivity and hubs;

Much of the theory of evaluation has been developed in the context of CBA, but many of these issues are very relevant in the case of impact models and CGE models.

\subsubsection{Noise and externalities}

CBA uses the established methods of quantifying externalities for airport projects, namely either revealed preference or stated preference methods (for an overview see de Rus, 2010). In practice, the "dominant method" (Boardman et al., 2017) of CBA in general, and particular for transport, is the hedonic pricing method. The effect of noise on house prices is measured by the noise depreciation sensitivity index defined as the percentage change in the house price due 
to a unit increase in the noise level. An early example occurs in the Roskill Study ${ }^{2}$ (Roskill, 1971). Based on various studies, the literature has established estimates for the shadow price for noise and other emissions (see Table 2). We note that compared to the 1970s substantial progress has been made to estimate the local external costs of air transport (Dings et al., 2003). CGE models typically do not measure externality costs directly, but estimates can be made in much the same way as with CBA, and the results added in.

\subsubsection{Distribution of Benefits and Costs}

Many, though not all, airport investments create benefits and costs which are unevenly distributed to individuals with different income levels. One option is to use a Kaldor Hicks potential compensation test, and not consider distributional issues - these can be dealt with using other policy instruments like income taxes. This standard approach has also been followed by most CBAs of airports. Nearly all studies put the distributional aspect aside (see Table 2). There are good reasons for this approach, partly because the distributional aspects depend on many factors which a partial method has difficulty in analysing. Earlier texts on CBA, such as those of Little and Mirrlees $(1968$; 1974) and Ray (1984) recommended that distributional effects be included in a CBA. One major difficulty in analysing distributional impacts is that what is needed is for the ultimate incidence to be estimated, but it is normally difficult to go beyond the initial incidence. A CGE approach can be very helpful in this regard. Since CGE models adopt a general equilibrium approach, it is straightforward to estimate gains and losses to different groups- i.e. ultimate incidence. Boardman et al., 2017) suggest using a "Distributionally Weighted CBA", which so far has not been applied to airports, to our knowledge.

\subsubsection{The Value of Time}

The value of time is almost always a critical parameter when evaluating airport investments. This is so because one of the major costs is the cost of travel time- time is used in accessing the airport and moving through it, and, in particular, where there are airside and landside delays (which are why additional airport capacity is being considered in the first place). The Roskill study was done soon after economists had become interested in the value of time, and it adopted the then developing approach. By the time of the Second Sydney Study, several other aspects had been recognised. For example, there was a recognition that time spent is not necessarily time wasted- a traveller might use the time in a plane for productive work. Other aspects included the disutility of time, employer on-costs and possible taxes (Carruthers and Hensher, 1976). There have been empirical studies, using surveys (Carruthers and Hensher, 1976) and revealed preference approaches. Currently, most countries and the EU have recommended time values for investment evaluation studies.

\subsubsection{Airport Pricing and Congestion}

One of the key reasons why investments are made in airports, either through additional runway or terminal capacity or new airports, is that demand is pressing on capacity. If nothing is done, delays will rapidly increase. The Roskill approach was to estimate the costs of delay with and

\footnotetext{
${ }^{2}$ This study is discussed in more detail in Section 4.1.1 below.
} 
without additional capacity - rather like the US system of delay rationing (Roskill, 1971; Abelson and Flowerdew, 1972). However, at the time of this study, it became recognised that increasing delay was an inefficient means of rationing airport capacity (Levine, 1969). If pricing were to be used, the need for additional capacity would be less and the additional capacity could be postponed for several years, at a considerable saving in cost (Forsyth, 1972). As it turned out, prices were not used in most busy airports. Rather the system of slot rationing developed- only flights for which the airline had a slot were permitted to use the airport (Czerny et al., 2008). The slot system effectively rations the airport rather than prices, and avoidable delays are not present. It is an effective system, assuming that slots are allocated efficientlysomething which is often not the case (in a world of uncertainty, either prices or slots can be the more efficient, depending on factors such as elasticities - see Czerny, 2008).

\subsubsection{Unemployment}

If there is unemployment in the economy, a recognised way of taking this into account in a CBA is to use a shadow wage different from a market wage (for example, use $80 \%$ of the market wage). For instance, Del Bo et al. (2010) show that a range of wage conversion factors can be estimated for a group of regions, on the level of unemployment. There are practical difficulties in implementing this recommendation - in working out what the shadow wage should be, and in determining how an investment affects employment. CGE models can help, particularly through estimating the implications of different labour market assumptions, though not in estimating shadow prices of labour. In popular discourse, airports are depicted as "job machines" and impact studies became popular as ways of illustrating (claimed) job benefits (see below). The proper treatment of the reduction of unemployment in an evaluation is of high practical importance. CBA differentiates between voluntary and involuntary unemployment.

\subsubsection{Land Use}

Handling land issues can often be a difficult problem for an evaluation, especially when a new airport is being evaluated. The value of the land on which the airport sits will typically depend on whether the airport is built or not- if it is built, the value of the land surrounding it will be higher (and potentially, the value of the land surrounding the old airport may fall). These types of issues need to be resolved. Even though demand may be pressing against capacity at the old airport, the new and old airports are unlikely to be good substitutes. Estimating demand and the split between the two airports is difficult. Pricing and regulation of the two airports will be an issue, how well slots allocate capacity, as will the travel time between the two airports and main centres of population.

\section{New Issues}

\subsubsection{Tourism Benefits}

Airports can be evaluated from a global or individual country / regional perspective. If a global perspective is used (e.g., see the European Investment Bank, 2013), there are no tourism benefits since all travellers belong to the globe. If an individual country perspective is used, (as was the case in the Second Sydney Airport study - see Australian and NSW Governments, 2012) there will be inbound and outbound benefits and costs. Tourism benefits can be a substantial proportion of the total benefits from an airport when the evaluation is being done 
from the perspective of a country or region - in the recent CBA of a new Sydney airport, almost $40 \%$ of benefits were accounted for by inbound tourism (Australian and NSW Governments, 2012). Tourism impacts are often measured in terms of changes in real GDP, capital formation, output in both tourism and non-tourism sectors resulting from changes in tourism expenditures. With tourism, which is an economy impact, it is important to avoid double-counting of effects, such those on employment and time savings.

Tourism benefits are the change in welfare as a result of additional inbound tourism. The importance of tourism benefits has long been recognised- the 1969 study by Ody (1969) puts high weight on them, though until recently, there were no rigorous methods of valuing tourism benefits. For example, in the recent Sydney study, inbound tourism benefits were assumed to be $25 \%$ of tourist expenditure (Australian and NSW Governments, 2012), - and the cost or benefit from outbound tourism zero. Outbound tourism costs or benefits are normally not measured - which is questionable. It is understandable that measuring tourism benefits is difficult- tourism benefits come about as a result of a large number of small effects in many markets. As a result, a CGE approach can shed some light on the costs and benefits of inbound and outbound tourism.

\subsubsection{Climate Change}

Concern about climate change has grown markedly over the past decade. As a result, climate change aspects now need to be factored into airport evaluation. For example, the Airports Commission has an extended discussion about the climate change assumptions it used when assessing airport strategies for London (Airports Commission, 2015b). Airlines are the main generators of greenhouse gases in aviation, though airports directly make a contribution. The main importance of airports is that they facilitate additional air travel and restrictions on airport developments have been actively advocated as a means of reducing gases.

Some externalities are essentially widely spread out in nature- a classic case is greenhouse gas emissions. The net effect of an airport investment on emissions could be quite different from the direct effect, since other effects come into play (for example, emissions from cars may fall). A CBA can include a shadow price of emissions of greenhouse gasses, though this would be a partial measure. A CGE study can provide a general equilibrium measure which takes indirect effects into account.

\subsubsection{Wider Economic Benefits, Connectivity and Hubs}

The economic evaluation of airports is now taking note of a range of disparate, though connected effects, often grouped under the term "wider economic benefits" or "wider economic impacts". This is reflecting what has been going on in the evaluation of surface modes (Graham, 2007; Venables, 2007), though the application of the concept in aviation is more recent. These benefits are in addition to the traditional benefits. In the surface transport context their existence has been suggested by the economic geography literature, and there is some evidence that they exist, though the measurement is difficult and their size is debatable (see Vickerman, 2013). As a result, when investment analyses are done, these are often treated separately from the main, well established benefits and costs, and noted as an additional benefit. Several can be identified, the borderline between is often fuzzy. The Airports Commission put 
much emphasis on connectivity benefits in its assessment of options for London (Airports Commission, 2015b).

An important aspect to note is that, even though the term "wider economic benefits" is the same for both surface transport and aviation, it means different things in different contexts. Estimates of WEBs are often made for surface transport evaluations, and the list of effects included is becoming fairly settled. WEBs are often listed below the traditional benefits and costs, partly because of the greater uncertainty surrounding them. They are often estimated to be around $10 \%$ of other benefits, though sometimes (less often now) rather more (for further details see Joint Study, 2012).

At this stage, the WEBs of air transport have been less researched, and discussion of them has been less systematic (see Pearce, 2013; Forsyth, 2020). Several suggestions have been made:

- Tourism benefits are sometimes regarded as WEBs of air transport (we have already listed them in this paper).

- Frequency externality benefits have long been listed as a benefit of air transport, and now might be considered as a WEB. Frequency benefits have been recognised as a benefit of other transport modes- see Mohring (1972). The Airport Commission includes them as a benefit, though not as a part of its WEI/WEBs estimates.

- There can be benefits from an expanded market and more competition- as yet, we do not know of any applications of effect in air transport.

- There may be benefits from air transport enabling an increase in labour supply and its productivity. It is not clear that there is any wider benefit from this, since users of air transport pay for their flights and internalise these benefits. However, passengers may not gain the full benefit from their output since they are taxed on it- there can be a WEB to the extent that extra output generates more tax. As yet, we do not know of any application of this in air transport.

These are some of the possible sources of WEBs in air transport. However, there is one source of WEBs which is now claimed to be a very large source of benefits- this is increased connectivity.

Connectivity is a term often used though less frequently defined (see Burghouwt and Redondi, 2013). There are benefits to travellers if an airport or city has more direct connections to other cities. For local residents, the time taken to access destinations will be less if the city is well connected. The benefits from greater connectivity are that travellers use less time and money to access their preferred destination access destinations, but a greater cost of interconnection.

There have been a number of attempts to measure the impacts from increased connectivity and air transport (see Forsyth, 2020 for a review). Several of these imply very large effects from increased connectivity - see PwC (2013). The common way of estimating them is to regress GDP or productivity on an index of connectivity. There is an issue of causality present- does additional connectivity cause higher GDP, or does higher GDP lead to greater connectivity? 
InterVISTAS (2006) analysed the link between additional connectivity and GDP- they found a positive link (this study recognised the causality issue) ${ }^{3}$. A more recent study has been that done for the London Airports Commission (2014). Most (or all) of the studies of connectivity benefits have been of impacts - they do not examine the connection between impacts and benefits. This is the difficult question, and it is not clear to what extent how much the increased connectivity creates a genuine WEB, or benefit which can be used in a CBA or CGE model.

Assessment of the WEBs of air transport and its relevance to airport evaluation is in its infancy and much remains to be done in sorting out the issues and developing measures. One question is will accounting for them make a large or small difference to investment evaluations? For many suggested WEBs the differences will be small, but a lot will depend on how large the benefits from increased connectivity are. If there are as large as some studies suggest, accounting for WEBs will have a significant impact on evaluations.

\subsection{Summary}

Table 2 provides a summary of how selected studies have addressed these problems.

\footnotetext{
3 See also Mukkala. K. and H. Tervo (2013)
} 
Table 2 Issues of CBA in Airport Investment Evaluation: Summary

\begin{tabular}{|c|c|c|c|c|c|c|c|c|c|}
\hline Study (year) & Noise & Distribution & Values of time & $\begin{array}{l}\text { Airport } \\
\text { Pricing }\end{array}$ & $\begin{array}{l}\text { Unemploym } \\
\text { ent }\end{array}$ & Land & $\begin{array}{l}\text { Tourism } \\
\text { Benefits }\end{array}$ & $\begin{array}{l}\text { Carbon } \\
\text { emissions }\end{array}$ & $\begin{array}{l}\text { WEBs/W } \\
\text { EIs }\end{array}$ \\
\hline $\begin{array}{l}\text { CBA } \\
\text { extension in Nicosia } \\
(1968)\end{array}$ & not applied & not applied & not applied & not applied & no effect & not applied & estimated & not applied & not applied \\
\hline $\begin{array}{l}\text { Grand Ouest Airport, } \\
\text { CE Delft (2011) }\end{array}$ & $\begin{array}{l}\text { acoustic study/ } \\
\text { population } \\
\text { within noise } \\
\text { zone }\end{array}$ & not applied & $€ 15.5$ & not applied & no effect & $\begin{array}{l}\text { valuation } \\
\text { of land }(€ \\
26 \text { million) }\end{array}$ & not applied & $\begin{array}{l}\text { shadow } \\
\text { pricing } \\
\text { method }\end{array}$ & not applied \\
\hline $\begin{array}{l}\text { Roskill commission } \\
\text { (1971) }\end{array}$ & $\begin{array}{l}\text { hedonic } \\
\text { pricing method }\end{array}$ & $\begin{array}{l}\text { not applied, } \\
\text { but later } \\
\text { studied }\end{array}$ & - & - & no effect & - & not applied & $\begin{array}{l}\text { not } \\
\text { covered }\end{array}$ & not applied \\
\hline $\begin{array}{l}\text { White Paper London } \\
(\mathrm{Dft}, 2003)\end{array}$ & acoustic study & applied & not applied & not applied & no effect & not applied & not applied & $\begin{array}{l}\text { carbon tax } \\
\text { on demand }\end{array}$ & applied \\
\hline $\begin{array}{l}\text { Lisbon } \quad \text { (NERA } \\
\text { Economic Consulting, } \\
2007)\end{array}$ & $\begin{array}{l}\text { acoustic study } \\
\text { of noise level } \\
\& \quad \text { hedonic } \\
\text { pricing }\end{array}$ & not applied & $\begin{array}{l}\text { value of time for } \\
\text { air travel } € 28.5\end{array}$ & not applied & $\begin{array}{l}\text { shadow } \\
\text { wages }\end{array}$ & $\begin{array}{l}\text { valuation } \\
\text { of land } \\
(€ 832 \\
\text { million) }\end{array}$ & not applied & $\begin{array}{l}\text { prevention } \\
\text { and } \\
\text { damage } \\
\text { cost } \\
\text { method }\end{array}$ & not applied \\
\hline $\begin{array}{l}3^{\text {rd }} \text { London airport } \\
\text { Nwaneri }(1970)\end{array}$ & $\begin{array}{l}\text { hedonic } \\
\text { pricing method }\end{array}$ & applied & - & - & no effect & - & $\begin{array}{l}\text { estimated } \\
\text { from } \\
\text { revenues }\end{array}$ & $\begin{array}{l}\text { not } \\
\text { covered }\end{array}$ & - \\
\hline $\begin{array}{l}\text { 2nd National Airport, } \\
\text { Central Planning } \\
\text { Bureau (1974) }\end{array}$ & acoustic study & not applied & not applied & not applied & no effect & $\begin{array}{l}\text { land } \\
\text { acquisition }\end{array}$ & not applied & $\begin{array}{l}\text { not } \\
\text { covered }\end{array}$ & not applied \\
\hline $\begin{array}{ll}\text { London } & \text { Airports } \\
\text { Commission } & \end{array}$ & acoustic study & $\begin{array}{l}\text { effects on } \\
\text { regions }\end{array}$ & $\begin{array}{l}\text { use of govt. } \\
\text { recommended } \\
\text { values }\end{array}$ & recognised & $\begin{array}{l}\text { recognised in } \\
\text { WEI } \\
\text { modelling }\end{array}$ & $\begin{array}{l}\text { cost of } \\
\text { additional } \\
\text { land } \\
\text { recognised }\end{array}$ & estimated & $\begin{array}{l}\text { emissions } \\
\text { assessed }\end{array}$ & $\begin{array}{l}\text { WEI } \\
\text { measured } \\
\text { with CGE } \\
\text { modelling }\end{array}$ \\
\hline $\begin{array}{l}\text { Chicago O'Hare } \\
\text { Modernization } \\
\text { Program }\end{array}$ & acoustic study & not applied & $\begin{array}{l}\text { Use of govt. } \\
\text { recommended } \\
\text { values }\end{array}$ & not applied & no effect & not applied & not applied & $\begin{array}{l}\text { not } \\
\text { covered }\end{array}$ & not applied \\
\hline
\end{tabular}




\section{An Evaluation of the Techniques}

\subsection{Cost Benefit Analysis}

\subsubsection{Brief Historical Perspective}

CBA is a well-established technique, and its advantages and disadvantages are well known (Jorge-Calderón , 2014). Airports have been analysed using CBA since the 1960s. We have surveyed some important ones (see table 2). The largest and most important study (perhaps ever) was that done by the Roskill Commission in the late 1960s/ early 1970s to evaluate the options for a Third London Airport. This was a very large study which set the scene for many decades to come. It provoked much discussion, both in the popular press and in scholarly journals (Mishan, 1970; Nwaneri, 1970; Paul, 1971). It assumed that scarce capacity would be rationed by delays, not prices or, as eventually, as it happened, slots (Abelson and Flowerdew, 1972; Forsyth, 1972). The 1970s saw a number of other large studies, particularly those of the Second Sydney Airport (Mills, 1982) and Amsterdam (Central Planning Bureau, 1974).

In both the UK and Australia, CBA was the preferred technique of evaluating airports. In Europe the European Commission (European Commission, 2014) has developed guidelines for assessing projects from cohesion funds since the 1990s. Since 2000 a CBA is mandatory for these projects which include transport projects and also airports. Some of these airports are financed through the European Investment Bank (EIB). The EIB demands a CBA for their funding decisions. The European Investment Bank (EIB) approach is a standardized CBA method including externalities (European Investment Bank, 2013; Jorge-Calderón , 2014) ${ }^{4}$. In the US a standardized CBA is required for airport projects such as the Modernization Program for Chicago O'Hare which preserves or enhances capacity. The total AIP (Airport Improvement Program) discretionary funds requested exceeds \$10 million (FAA, 1999).

The question of further capacity is now again an issue for Sydney and London. In both cases the evaluation is breaking new ground in terms of technique. The Sydney study was produced in 2012 (Australian and NSW Governments, 2012). This study uses a conventional CBA approach. However, the study also includes a CGE study of some aspects (e.g., timing). In particular, the study estimates the impact on (GDP and other variables) of not building the additional capacity (but the CBA measured the cost of building it). The Airports Commission $(2014 ; 2015 b)$ from London is a further step in the application of a CBA and a CGE model for airport investment evaluation. The relationship of the different parts of the exercise is not very well explained - a very useful outline of some of the problems is contained in the note from Expert Advisors (Airports Commission, 2015a). An important exercise done during the process of the inquiry was an estimate of the wider economic impacts of the options - with the results

\footnotetext{
${ }^{4}$ The benefit of projects is measured using the standard transport sector framework of generalized cost of travel. The sources of the benefits of investing in landside capacity are threefold. First, to avoid traffic diversion as passengers follow alternative travel arrangements. Traffic diversion can take place in two ways: in time and in mode. The second source of benefit would be relieving congestion in terminals, reducing user throughput time. The third source of benefit is generated traffic, consisting of traffic that would not have travelled at all without the project.
} 
from the traditional CBA fed into the CGE model (Airports Commission, 2014). There is an estimate of the frequency benefits, but the main change comes from an estimate of higher productivity enabled by the investment. Ultimately, this estimate uses econometric estimates, not properties of the model (this is typical of estimates of wider economic impacts with aviation and surface transport).

\subsubsection{CBA in Perspective}

CBA is a very well researched and accepted technique. In the airport context, it has been able to provide rigorous evaluations and address several difficult problems. However, familiarity need not blind us to its limitations. These are several:

- It is typically a partial equilibrium technique, whereas ideally, a general equilibrium approach should be used;

- It has difficulties in handling complex tax effects (including those where WEBs are being measured) accurately since it is a partial equilibrium approach which does not measure effects in markets other than the markets directly affected;

- It does not handle nonlocal externalities, such as externalities which affect whole economies (or indeed the world), such as the overall climate change effect of an airport, accurately since it is a partial equilibrium approach which does not measure effects in markets other than the markets directly affected;

- It is limited in evaluation when there is unemployment in the economy.

- It does not measure benefits or costs which are spread out throughout the economy, such as the benefits or costs of tourism, well, and

- It does not handle other than immediate incidence of costs and benefits well- ultimate incidence it what is required for a rigorous evaluation.

- There are new types of benefits and costs which may have a role in evaluations: these include tourism benefits (which can be measured rigorously) and wider economic benefits/impacts, which could be quite significant, though the measurement of these is in its infancy.

This poses the question- can the other techniques, Economic Impact and CGE models help in gaining a better overall evaluation of an airport?

\subsection{Economic Impact Analysis}

\subsubsection{Using EIA in Airport Evaluation}

The input-output analysis describes the linkages between the production sectors in an economy (Leontief, 1987). Developed in the 1930s and 1940s it was used to measure the amount of factor inputs required to produce a given set of outputs. By identifying these linkages, EIA, 
which has been developed from it, is able to provide estimates of how much factor use, or factor demand, will change throughout the economy when output is expanded. Our survey shows that $\mathrm{EIA}^{5}$ is used for three distinct purposes (see Table 3 and appendix):

a. Measuring economic significance;

b. Measuring regional economies of scale and agglomeration; and

c. Criterion for investment

We explain this in turn, explain thereafter how EIA analyses catalytic effects which are similar to wider economic benefits and then criticize EIA as a tool to assess airport investment.

a). Measuring Economic Significance. The use of EIA as a tool to document the economic contribution (i.e., essentially how large in terms of key economic variables such as gross product and employment) of an airport to a regional economy can be best illustrated by the example of Vienna Airport which has a study of the economic significance of its airport in 2007 (Fritz et al., 2007). The study uses an extended IO-model and estimates that the 16,031 full time employed workers at the airport generate additional indirect and induced jobs of a magnitude of 52,500. The report does not link these results to any decision on investment or any policy issues like noise or emissions. The airport reports these results as "economic significance" and avoids any hints to policy issues. We have found similar studies at a number of European airports and US-airports (see below table 3).

\footnotetext{
${ }^{5}$ Input-Output models have been developed further to incorporate dynamic effects. However, to the best of our knowledge are not aware of any airport study using a dynamic version of input-output model
} 
Table 3: Economic Impact Studies

\begin{tabular}{|c|c|c|c|c|c|}
\hline Country & Airport & Author (Year) & Purpose & $\begin{array}{l}\text { Main Results Employment } \\
\text { Impact (additional jobs) }\end{array}$ & Catalytic effects \\
\hline Austria & Vienna & Fritz et al. (2007) & Significance & $\begin{array}{l}\text { Direct: } 16,031 ; \\
\text { Indirect/Induced: 52,500. }\end{array}$ & No \\
\hline \multirow[t]{7}{*}{ Germany } & Frankfurt/Main & Hujer et al. (2004) & Policy criteria (Expansion) & 1.77 (multiplier) & No \\
\hline & Munich & $\begin{array}{l}\text { Basler and Bulwien (2007): } \\
\text { impact in } 2005\end{array}$ & \multirow[t]{2}{*}{ Policy criteria (3rd runway) } & $\begin{array}{l}\text { Direct: } 27,400 \\
\text { Indirect/Induced: } 30,140 .\end{array}$ & \multirow[t]{2}{*}{ Yes (but unclear how) } \\
\hline & & $\begin{array}{l}\text { Basler and Bulwien (2007): } \\
\text { impact in } 2025\end{array}$ & & $\begin{array}{l}\text { Direct: } 8,221 \\
\text { Indirect/Induced: } 16,700\end{array}$ & \\
\hline & Hamburg & Empirica (1996) & Regional analysis & $\begin{array}{l}\text { Direct: } 12,000 \\
\text { Indirect/Induced: } 32,500\end{array}$ & No \\
\hline & \multirow[t]{2}{*}{ Berlin } & $\begin{array}{l}\text { Baum et al. (2005) } \\
\text { Results for BBI } 2012\end{array}$ & \multirow[t]{2}{*}{$\begin{array}{l}\text { Rationale for new BBI } \\
\text { airport }\end{array}$} & $\begin{array}{l}\text { Direct: } 17,100 \\
\text { Indirect: } 7,700 \\
\text { Induced: } 3,600\end{array}$ & \multirow[t]{2}{*}{ Yes $(36,000$ jobs by new $\mathrm{BBI})$} \\
\hline & & $\begin{array}{l}\text { Baum et al. (2005) } \\
\text { BBI } 2012 \text { versus Berlin } 2004\end{array}$ & & $\begin{array}{l}\text { Direct: } 3,700 ; \\
\text { Indirect/Induced: } 3,400 .\end{array}$ & \\
\hline & Kassel & Klophaus (2013) & $\begin{array}{l}\text { Rationale for regional } \\
\text { airport }\end{array}$ & $\begin{array}{l}\text { Direct: 725; } \\
\text { Indirect/Induced: } 1,315 .\end{array}$ & $\begin{array}{l}\text { Yes (389 jobs from incoming } \\
\text { tourist) }\end{array}$ \\
\hline Italy & Milano & CLAS and SACBO (2005) & Regional Analysis & $\begin{array}{l}\text { Direct: } 3,601 \\
\text { Indirect: } 1,116 \\
\text { Induced: } 2,523\end{array}$ & No \\
\hline Netherlands & Shiphol & Haakfort et al. (2001) & Regional analysis & 2.0 (multiplier) & - \\
\hline Spain & Aeropuerto de Vitoria & $\begin{array}{l}\text { Macho et.al. } \\
\text { (1999) }\end{array}$ & Regional Analysis & $\begin{array}{l}\text { Direct: } 343 ; \\
\text { Indirect/induced: } 372 ;\end{array}$ & No \\
\hline Switzerland & Zurich & Infras (2005) & $\begin{array}{l}\text { Policy criteria (loss of hub } \\
\text { carrier/ movement cap) }\end{array}$ & $\begin{array}{l}\text { Direct: } 3,080 \\
\text { Indirect: } 1,055 \\
\text { Induced: } 6,383\end{array}$ & $\begin{array}{l}\text { Yes }(2,636 \text { jobs from incoming } \\
\text { tourist) }\end{array}$ \\
\hline UK & Edinburgh & York Aviation (2009) & $\begin{array}{l}\text { Policy Criteria } \\
\text { (Masterplan/ expansion) }\end{array}$ & $\begin{array}{l}\text { Direct: 3,530; } \\
\text { indirect/induced: 7,680. }\end{array}$ & No \\
\hline USA & Atlanta & $\begin{array}{l}\text { Dept. of Aviation Atlanta } \\
\text { (2009) }\end{array}$ & Significance & $\begin{array}{l}\text { Direct: } 237,845 ; \\
\text { Indirect/Induced: } 196,589 .\end{array}$ & No \\
\hline
\end{tabular}


b). Measuring regional economies of scale and agglomeration. EIA can analyse the dynamic effects of external economies in the Marshallian sense (cf. Marshall 1920, Krugman, 1991). IO-analysis can identify the locational structure of industries clustering around airports and it can lead to a better understanding of clusters and provide useful information for the planner of business locations. There are a number of studies in our sample like the study on Schiphol Airport (Hakfoort et al., 2001) and Hamburg Airport (Empirica, 1996) which try to identify backward and forward linkages within the region. But these studies are rather descriptive, and the studies do not use input-output tables to identify clusters (for an overview of this approach see Lublinski, 20016).

c. As a Criterion for investment. EIA has been used extensively as an investment criterion since the 1980s, in both the US and Europe. The FAA developed guidelines for the use of impactanalysis in response to the airport community in 1986, which were updated in 1992 (Butler and Kiernan, 1986 and 1992). The Transport Research Board evaluated the actual practice in 2008 (ACRP, 2008). The FAA guidelines reflect an ambivalent approach. On the one hand, it states that EIA should not be used as a substitute for CBA in the master planning process of US airports (Butler and Kiernan, 1986, p 1). But after evaluating more than 30 case studies in the US ACRP (2008, p. 8) concluded that the main purpose is to justify airport expansion that is to answer the question a CBA is supposed to answer.

The FAA guidelines were adopted by ACI-Europe (the airport industry association) in the 1990s and became the official strategy for many airports such as Frankfurt Airport. Frankfurt Airport planned a new runway, although the last extension caused violent protests. To assess these plans, a mediation process was established. The objective of mediation was to find out "under which circumstances Frankfurt Airport can help to keep up permanently and enhance the competitiveness of the Rhine-Main region with respect to employment and economic structure, without neglecting the ecological costs imposed on the region" (quoted from Hujer and Kokot, 2001, p. 112 ). On behalf of the three mediators, studies about the economic, ecological, and social consequences were conducted. Five scenarios were defined, ranging from the status quo, a reduction of aircraft movements to a full-scale expansion. The results of the EIA (Bulwien et al., 1999) were decisive for the final recommendation. The result was, while in the status quo 142,000 jobs directly or indirectly depended on the airport in the State of Hessen, a full-scale expansion would create another 57,000 jobs. Then the mediation group weighed the different scenarios and concluded to recommend the full-scale expansion, because of the economic importance of the project for the region, i.e. because of the 57,000 new jobs. Due to these overwhelming economic effects, it was argued that citizens would have to accept the ecological costs.

Our survey shows that out of 32 studies in nine European countries EIA was initially used to show the economic significance (16\%) and the regional effects of airports (25\%), but this purpose became less and less important. The majority of studies (59\%) serves a clear policy purpose that is to support the expansion of existing airports, building of new airports, subsidises for regional airports and preventing stricter night curfews (see appendix). In this respect Europe

\footnotetext{
${ }^{6}$ Such cluster analysis is confined to input-output tables excluding induced effects.
} 
differs from the US and Canada where the purpose of the study at least officially documents the economic significance but also serves the purpose to rationalize airports investments (ACRP, 2008, p. 8).

\subsubsection{Measuring Catalytic effects}

Just as, in the cost-benefit literature, there has been a broadening of the list of benefits and costs, corresponding to "wider economic benefits", EIA literature has recognized possible "catalytic effects" associated airport investment. Traditionally, impact studies did not include catalytic effects, as impact focus entirely on the demand effects of an airport investment. However, there is a tendency to change this. This is reflected in the US literature on impact studies. The guide for impact studies from the year 1992 does not mention catalytic effects at all, but the ACRP (2008) overview recommends the "catalytic method" in Europe of the study by Cooper and Smith (2005) for Eurocontrol.

Our survey shows that there is a large variance regarding the definition and measurement of impact studies, and the interpretation of catalytic effects. Most studies, though not all, agree that catalytic effects are related to the supply side of the economy. York (2004) in the study for ACI-Europe defines the catalytic impact as "employment and income generated in the economy of the study area by the wider role of the airport in improving the productivity of businesses and in attracting economic activities such as inward investment and inbound tourism" (p.5). This is in line with traditional impact studies, which separately analyse airports as a locational factor, namely that airports offer connectivity to businesses which locate their business in the airport region, leading to regional economies of scale. Defined in this way, catalytic effects share elements of wider economic benefits/impacts as analysed in CBA and CGE studies.

Traditional impact studies used to analyse the catalytic effects qualitatively by undertaking surveys asking how important air transport is for locational choices. The overall result was that airports were seen as a necessary but not sufficient condition to locate a business in a region thereby strengthening regional competitiveness. The new studies try to quantify at least some parts of catalytic effects, and either add the effects in terms of jobs and value-added, or avoid adding up and provide the catalytic effect as an important "additional" factor.

The study of Baum et al. (2007) is an important example of such a new type of EIA. Baum analyses the effects of the New Berlin Airport (BBI) by comparing economic impact and the catalytic effects of the existing Berlin Airports with the new centralized airport. The impact in terms of direct, indirect and induced jobs is rather small. BBI creates just 7,000 new jobs. Baum et al. (2007) also quantify the catalytic effects stemming from inbound and outbound tourism, reduced travel costs and relocation of business in the Berlin area. The catalytic effect of BBI is supposed to be of a magnitude of 32,400 new jobs. It is the decisive factor for BBI because Baum et al. argue that BBI has only a small impact in terms of direct, indirect and induced jobs, but a big impact in terms of catalytic effects. With this result Baum et al. (2007) break new grounds because this airport project is the first project recommended just because of its catalytic impact. 


\subsubsection{Criticisms of the use of EIA models}

If EIA is used for investment assessment, it leads to irrational decisions (see also Waters, 1976, Malina and Wollersheim, 2007) ${ }^{7}$. Amongst other deficiencies, EIA makes the following six mistakes:

Confusing Benefits and Costs. The above argument that an investment creates a certain number of additional jobs, and that these are the benefits of a project, declares the inputs of the project as outputs, or put it differently, it redefines costs as benefits. Labour and wages are a cost of a project. Only to the extent that a project reduces involuntary unemployment benefits are created (De Rus, 2010).

No scarcity of resources. In the model world of impact studies resource are not scarce. Using resources for airport investment have no opportunity costs (Walters, 1997). Hence there are no price effects. This is obviously wrong in core regions where resources like land are limited and where very often labour is also scarce. Factors could be drawn from outside. This would come at a cost for the rural region as well as for the central region. It does not have to be negative. The point is that these effects are neglected.

Inefficiencies increasing the impact. Assume that there are two airport projects with the same amount of passengers and freight, but with differences in labour productivity, wages, efficiency, investment costs, and geographical distribution of suppliers. Ceteris paribus, according to EIA, the project with lower productivity and lower wages should be selected because more labour is necessary in the production of the direct and the indirect product and because low wage workers have a higher marginal propensity to consume leading to stronger induced. If the decision were between a new 'gold plated' traditional terminal and cost efficient innovative terminal, EIA favours the first one because the direct and indirect effects are ceteris paribus higher as the production needs more resources. If the first project uses only locally produced goods, while the latter uses all the resources of a globalised world economy its indirect effects would be greater than those of the latter. Obviously, taking IO-analysis as guidance leads to unproductive and inefficient airports (Niemeier, 2001).

Ignoring substitution effects. In case of an airport extension, traffic is diverted from one airport to another airport. This substitution effect leads to further substitution effects in the vertical chain of production. Assuming a Leontief production technology implies either that the effects are relatively small or that for modelling reasons such as simplification as appropriate. While the latter might be acceptable the former conflicts with the view that airport extensions lead to catalytic effects with the relocation of business and jobs.

\footnotetext{
${ }^{7}$ Airports are not the only case in which EIA is misused to assess investment or a particular policy. In air transport, the issues of open skies and passenger ticket tax are sometimes "evaluated" by EIA. In other modes of transport CBA seems to be more dominant and EIA plays a minor role, but there might be exceptions for ports or cruise ships. Tourism events like Olympic games, and many other decisions of the government like investments in public housing might be other cases. It is beyond the scope of this paper to analyse this. There is not much literature on this misuse of EIA. See Grady and Müller (1986).
} 
Induced effects are independent of the project. The induced effects are a fifth or third of the total effects (see table 3), but they are independent of the airport investment (Pfähler, 2001). They would also occur if income is used for on other projects (Niemeier, 2001 and Thießen, 2009).

Ill-defined Catalytic effects. Catalytic effects of impacts studies and wider economic benefits of CBA /CGE have in common that they are trying to analyse the same phenomena, but with different concepts and methods. The phenomena are that air transport can lead to more tourism and can create connectivity and agglomeration economies. Some of these are benefits some are costs. Impact studies treat all effects except tourism to foreign countries as additional impact and hence benefit. In addition, the method of impact studies is so far rather descriptive and takes for granted ${ }^{8}$ that airport investment is causing productivity gains from regional economies of scale and agglomeration economies. Adding as benefits to the direct indirect and induced effects the catalytic effects is like adding apple and pears. Some impact like the reduction of unemployment or time savings are real benefits others impacts like the costs for labour are not and the latter ones are dominating the former.

In Table 4 below the difference between the concepts of catalytic effects, WEBs and WEI are summarised.

Table 4 The Relationship between Catalytic Effects, WEBs and WEIs

\begin{tabular}{|c|c|c|c|}
\hline & Catalytic & WEB & WEI \\
\hline Crowding Out & No & Yes & Yes \\
\hline $\begin{array}{ll}\text { General } & \text { Equilibrium } \\
\text { Effects } & \end{array}$ & No & Yes & Yes \\
\hline Impact on Output & Yes & NA & Yes \\
\hline Impact on Employment & Yes & Yes & Yes \\
\hline Connectivity & $\begin{array}{l}\text { Yes- impact on } \\
\text { output }\end{array}$ & $\begin{array}{l}\text { Yes-impact on } \\
\text { welfare }\end{array}$ & $\begin{array}{l}\text { Yes-impact on } \\
\text { output }\end{array}$ \\
\hline Tourism Inbound & Yes & Yes & Yes \\
\hline Tourism Outbound & $\begin{array}{ll}\text { No } & \text { (with } \\
\text { exceptions) }\end{array}$ & Yes & Yes \\
\hline Scale Economies & Yes in principle & Yes & Yes \\
\hline Welfare & No & Yes & NA \\
\hline
\end{tabular}

First of all, catalytic impacts do not take account of crowding out; WEBs/WEIs do. This is because price effects are not part of the analysis. Secondly, catalytic impacts do not take into account general equilibrium effects; WEBs/WEIs do (e.g. tax effects, effects of imperfect competition). Again this is due to approach to ignore price effects and rely on a rather simple model. Thirdly catalytic impacts provide a measure of a change in output; WEIs also do, although smaller and can even be negative. Fourthly, catalytic impacts provide a measure of

\footnotetext{
${ }^{8}$ InterVISTAS (2015) is a notable exception.
} 
the always positive impact on employment. Instead WEBs as well as WEIs provide a measure of the benefits, which can be either positive or negative of the change in employment. Fifthly, catalytic impacts can provide a measure of connectivity effects, but not of the benefits of connectivity. WEBs can provide a measure of the welfare benefits from a change in connectivity while WEIs provide a measure of the output impacts from changed connectivity. All connectivity estimates are derived econometrically. Sixth, Catalytic impacts provide a measure of the (positive) change in inbound tourism receipts; WEBs provide a measure of the welfare benefits (positive or negative) of a change in tourism; WEIs provide a measure of the smaller positive or negative change in tourism receipts because only part of the impacts are benefits or costs. Seventh, catalytic impacts very often do not provide a measure of changes in outbound tourism receipts. WEIs do not neglect these effects and provide a measure of the change in outbound tourism expenditures. WEBs provide a measure of the (positive or negative) benefits from a change in outbound tourism. Eight, catalytic impacts can, in principle, provide a measure of the output impacts arising from scale economies; WEBs can measure the benefits from reaping scale economies; WEIs can provide a measure of the output impacts from reaping scale economies. Ninth, catalytic impacts cannot measure welfare benefits; WEBs do measure welfare benefits.

It is important to note: because catalytic impacts do not take account of crowding out and general equilibrium impacts, the measured impacts on output, employment, and inbound tourism will be substantially higher than the impacts as measured using WEIs.

\subsection{Using Computable General Equilibrium Models for Evaluation}

\subsubsection{Brief Historical Perspective}

In recent years, there has been the use of CGE models in the evaluation of investment generally, and in particular, airport investment. In Australia, Europe and Japan, there has been growing use of CGE models in transport evaluation over the last 20 years, and many major projects are subjected to both CBA and CGE evaluations. Most of these studies have all used static, multisectoral and national CGE models, without any spatial modelling, explicit specification of land use, distances, travel time and surface transport congestion. There is now a branch of CGE modelling, which is including these spatial dimensions- these are, particularly useful in analysing transport economics questions (see, Bröcker and Mercenier, 2011). These models are useful in analysing some airport evaluation issues.

An early study was that of Melbourne airport (Melbourne Airport, 2003). The objective was to assess the gain from the airport being curfew free - see Madden for further discussion of this study (Madden, 2004). More recent studies have included a study of the Western Sydney Region (NSW Business Chamber, 2013) and an evaluation of a second runway at Brisbane airport (Brisbane Airport, 2007). A substantial study was that done of a new airport for Sydney, in 2012 (Australian and NSW Governments, 2012). The study included a conventional CBA of whether the airport should go ahead, and it also included a CGE analysis of the costs of not going ahead with the airport. Both approaches came to the same broad conclusion, though they 
were not integrated in any way. Beyond Australia, the CGE approach has been used to evaluate an airport investment in Japan (Ueda et al., 2006). In the UK, the Airports Commission used a spatial CGE approach, in addition to a CBA approach, to analyse the options for additional airport capacity for London (Airports Commission, 2014; 2015b). In many ways, this study was a major step forward on the use of CGE model as a means of evaluating airport investments.

\subsubsection{Resolving issues with the use CGE models}

Just as with CBA, there are a number of issues which need to be resolved if CGE models are used in airport investment evaluation (see below Table 4). Some of the more important ones are as follows:

- Welfare Measurements

- The Level of Disaggregation

- Tourism Benefits

- Externalities and Non Market Goods

- Exploring Impacts of Unemployment

- Validation 
Table 5: CGE Studies of Airports

\begin{tabular}{|c|c|c|c|c|c|c|c|}
\hline Airports & Type of Study & $\begin{array}{l}\text { Welfare } \\
\text { Measure }\end{array}$ & $\begin{array}{l}\text { Exter- } \\
\text { nalities }\end{array}$ & Tourism & $\begin{array}{l}\text { Unemploy- } \\
\text { ment }\end{array}$ & $\begin{array}{ll}\text { Level } & \text { of } \\
\text { Disaggregation } & \end{array}$ & Comments \\
\hline $\begin{array}{l}\text { Melbourne } \\
2003\end{array}$ & Impact of Curfew & no & No & Implicit & $\begin{array}{l}\text { flexible labour } \\
\text { market }\end{array}$ & 36 & Dynamic model \\
\hline $\begin{array}{l}\text { Brisbane } \\
2007\end{array}$ & New Runway & no & No & Implicit & $\begin{array}{l}\text { flexible labour } \\
\text { market }\end{array}$ & - & Limited detail \\
\hline $\begin{array}{l}\text { Sydney } \\
2012\end{array}$ & $\begin{array}{l}\text { Additional } \\
\text { Airport }\end{array}$ & no & No & $\begin{array}{l}\text { Limited } \\
\text { explicit } \\
\text { discussion }\end{array}$ & $\begin{array}{l}\text { flexible labour } \\
\text { market }\end{array}$ & $\begin{array}{l}144 \text { industry sectors } \\
\text { in } 57 \text { regions }\end{array}$ & $\begin{array}{l}\text { The Enormous Regional } \\
\text { Model (TERM) general } \\
\text { equilibrium model }\end{array}$ \\
\hline $\begin{array}{l}\text { Tokyo Haneda } \\
2005\end{array}$ & New Runway & yes & No & Implicit & fixed & - & spatial model \\
\hline $\begin{array}{l}\text { London } \\
2014\end{array}$ & $\begin{array}{l}\text { Multiple } \\
\text { Investments a } \\
\text { several airports }\end{array}$ & no & Yes & $\begin{array}{l}\text { Some explicit } \\
\text { discussion }\end{array}$ & Fixed? & 11 & spatial model \\
\hline $\begin{array}{l}\text { Airports in } \\
\text { Australian } \\
\text { Regions } \\
2007\end{array}$ & $\begin{array}{l}\text { Study of Benefits } \\
\text { and Impacts of } \\
\text { Subsidies }\end{array}$ & Yes & No & $\begin{array}{l}\text { Explicit } \\
\text { Tourism } \\
\text { Model }\end{array}$ & $\begin{array}{l}\text { Fixed and } \\
\text { Variable }\end{array}$ & $50+$ & - \\
\hline $\begin{array}{l}\text { Western } \\
\text { Sydney } 2013\end{array}$ & $\begin{array}{l}\text { Study of Impacts } \\
\text { on Western } \\
\text { Sydney and Rest } \\
\text { of Sydney }\end{array}$ & No & $\begin{array}{l}\text { No- } \\
\text { capability of } \\
\text { model not } \\
\text { used }\end{array}$ & Implicit & $\begin{array}{l}\text { Flexible labour } \\
\text { market }\end{array}$ & 13 & $\begin{array}{l}\text { Dynamic multi-regional } \\
\text { CGE }\end{array}$ \\
\hline
\end{tabular}




\subsubsection{Welfare measurements}

CBA is a means of measuring the net social benefit (NSB) of a project. With a CGE model, there can be several outputs (GDP, consumption and employment), and NSB may not be one of them. Though it is straightforward to include a welfare measure equivalent to NSB within a CGE framework, most studies, especially Australian studies, do not have a welfare measure. However, it is worth mentioning that several European studies have a specific welfare measure (Bröcker and Mercenier, 2011). Alternatively, more simply, estimates of GDP or GNP can be adjusted to develop a proxy, which approximates NSB (see Dixon, 2009). Most CGE airport investment studies measure GDP while CBAs measure NSB (e.g. the Brisbane and Sydney studies). These are very distinct measures- however, it is easy for CGE studies to report the impact on NSB, and if this is done, for the two types of studies to be quite comparable.

\subsection{The Level of Disaggregation}

CGE models are complete models of the economy but are only useful in the evaluation of investment projects if they represent a good approximation of the working of the economy concerned. One key issue in constructing a CGE model includes the nature and degree of disaggregation in terms of sectors and households. A related issue is how the introduction of the investment is to be modelled. When an aggregate model is used, or the incorporation of the investment is not explicit, results would tend to be inaccurate. If this is the case, it is common for analysis to take place at a lower level of aggregation by constructing a sub-model capable of capturing the key features of the airport investment. As yet, the aggregation issue has not been explored much when CGE models are applied to airport investments.

Another aspect of disaggregation includes the level of spatial detail. Though CGE models with a spatial dimension have been applied to transportation infrastructure appraisal (e.g. Buckley, 1992; Bröcker et al., 2010; Tscharaktschiew and Hirte, 2012), their application to airport investment appraisal is not widespread.

\subsubsection{Tourism Benefits}

The disaggregation of branches in a CGE model makes it possible to estimate the gains from inbound tourism and the costs of outbound tourism. However, this has not been the case, as the results from most studies (e.g. Sydney Study) are highly aggregated, and not broken down to specific benefits or costs. As noted before, inbound tourism benefits can be (claimed to be) around $40 \%$ of total benefits for a large city airport and more for an airport in a leisure destination. Several CGE studies suggest that the benefits from inbound tourism or costs of outbound tourism are around 5-10\% (see Dwyer et al., 2006; Blake, 2009; Dwyer et al., 2013; Forsyth et al., 2014; Njoya, 2020). There have been studies done on the impact of air taxes on the UK economy, which, amongst other things, have a measure of tourism benefits ( $\mathrm{PwC}$, 2013). Using the results of CGE models, it is possible to gain rigorous estimates of tourism benefits which can be incorporated in a CBA of an airport investment.

\subsubsection{Externalities and Non Market Goods}


It is straightforward to include nonmarket goods such as leisure time in a CGE evaluation - the valuation can be handled in the same way as it is in CBA. Leisure time is a large proportion of the costs and benefits of airport investment, affecting airport delay costs and access transport costs. Again, however, the correct evaluation of leisure time may not be as simple as invariably assumed in CBA (Forsyth, 1980). This is an aspect which has yet to be explored (these aspects have been examined in the context of measuring the WEBs of surface transport- see Venables, 2007).

\subsubsection{Exploring the Impacts on Unemployment}

If there is unemployment in the economy, an airport project may not reduce labour available to other industries much or at all. In CBA, this is reflected in a shadow wage being less than the market wage. The principle is easy to enunciate, but measuring the shadow wage is very difficult, given the general equilibrium nature of the problem. A CGE approach to investigating labour force impacts can be helpful, though there are practical limitations to its contribution neither technique can measure the shadow wage. Many CGE models have very simple labour markets and do not investigate the sensitivity of their results to different labour market assumptions. It may be possible to come up with a range of possible values and the impacts on the investment's NSB.

\subsubsection{Validation}

Validation is an important step in the analysis of results of a CGE model. Essentially, the model must be tested to ensure that it is a correct representation of reality. While there are some CGE models of airports, which have now been used, it is not clear how robust the validation of these models has been.

As with CBA, ex-post studies are of value, even though rare. In the case of a CGE modelling study, it is possible to compare forecasts as against actuals, and if they are different, re simulate the shock, to estimate results based on actual data, not just forecast data. As yet, this has not been done in the case of airport evaluations.

\subsubsection{CGE Modelling Studies in Perspective}

CBAs have been applied to airports for around 50 years. In contrast, CGE models have been applied to airport investment evaluation for only 15 years or so. As a result, there are still major problems to be resolved- for example, the issue of model results and welfare measures, the treatment of externalities and non-market goods, the use of the CGE approach in the measurement of difficult-to-value costs and benefits such as tourism, and the contribution of CGE models in measuring the full general equilibrium rather than the partial equilibrium results as provided by a CBA.

\subsubsection{Capturing General Equilibrium Effects}

A CGE model can measure GE effects, though a typical CBA cannot, though often some indirect effects are measured. The magnitude of the indirect effects will depend on the presence and extent of distortions in the market. GE effects of a CGE model can be compared with the 
results of a CBA study- this would be instructive to do, and it would be easy to do, but as yet, this has not been done. The Sydney and recent London studies include both a CBA and a CGE study, but there is no attempt to compare results to determine how big a difference measuring GE aspects makes, other than for specific evaluation issues such as non-local externalities or widely spread benefits such as tourism benefits.

Two other aspects which a CGE model can evaluate but which a CBA cannot are economywide (as distinct from local) externalities (such as the impact on and costs of) greenhouse gas emissions, and distribution. CGE models can allow for externalities and nonmarket goods, such as noise, carbon dioxide emissions and climate change effects. Currently, there are several models which have greenhouse gas emissions as one of the "outputs" of the model (these are calculated by multiplying the emissions intensity of each industry by its output). An example is that of Adams et al. (2000). This makes it possible to estimate the overall emissions from Australia as a result of a change, such as the expansion of an airport.

In a small number of cases, there has been an attempt to assess distributional impacts of airport investments (Nwaneri, 1970; the MANS study of Sydney Airport in the 1970s- see Mills, 1982). The problem with CBA is that it can only handle immediate incidence effectsdetermining ultimate incidence is quintessentially a general equilibrium problem. As a result, most airport studies do not take distributional impacts into account. If a CGE model allows for different income classes (or other groups of consumers, such as urban and rural), it can be used to determine ultimate incidence.

\subsubsection{Analysing the Impacts of Employment Assumptions}

In investment evaluation, one of the most important assumptions is that of determining how the labour market works. Moreover, the results of the model are a reflection of the assumptions made about the market, such as the extent of wage flexibility and mobility of labour. A CGE model is very useful in examining the implications of different labour market assumptions. Although few studies comparing CBA and CGE estimates have been reported in the literature, doing this would have at least two distinct advantages. Firstly, evaluations using the two techniques can be compared like-for-like, and secondly, doing so would provide a conservative estimate of the NSB of the project- one not dependent upon on questionable labour force assumptions. Despite this, we have not yet seen examples of this being done.

\subsubsection{Sensitivity Analysis}

Good CBA and CGE studies include sensitivity analyses to illustrate how sensitive the results are to alternative parameter values (e.g. values of time) and assumptions (full employment or not). With CGE evaluations, this is easy, since it simply involves doing more simulations of the model, which is both cheap and quick. The problem with a CGE evaluation is how to present the results in a way, which makes effective use of the large amount of information, which a CGE study can produce.

\subsubsection{Measuring WEBs using CGE Models}


CGE models can be useful in measuring WEBs (or WEIs) of air transport, though not all aspects of WEBs can be estimated using a CGE model. For example, effects on productivity in the economy need to be estimated by other means, such as econometrically. One aspect of WEBs comes about as a result of market power and taxes in the economy- CGE models are useful ways of estimating these effects (see, e.g., Venables, 2007; Forsyth 2020). Thus, a CBA could use an estimate of WEBs of air transport derived in part from a CGE study. The CGE study of London airport options done for the Airports Commission (2014) especially saw the CGE model as a means of measuring WEIs.

\section{Concluding Comments}

We have analysed three techniques for evaluating an investment in Airports:

- Cost Benefit Analysis (CBA), which is based on a strong theoretical foundation, is practical and easy to interpret;

- Economic Impact Analysis (EIA), which has become quite popular, but which is not rigorous and is misleading, and

- Computable General Equilibrium (CGE) modelling, which has only recently been used for airport evaluation, but which is strongly based in theory and can handle evaluation issues which CBA cannot.

For the reasons given in the paper, we strongly discourage the use of EIA. This recommendation is not new. Waters (1976) criticised the use of EIA convincingly in the 1970s when he was confronted with impact studies in almost any public project. Impact studies cannot evaluate effects was his message. Unfortunately, this message got lost, at least for airports. In the 1980s the airport industry developed the strategy to rationalise airport expansion with the direct, indirect and induced jobs airports were supposed to create. The values generated by EIA have been large and got even larger as from about 2005 onwards, with the airport industry claiming to create even more jobs through catalytic effects. We argue that this strategy is misleading and does not lead to a rational dialogue if an airport investment makes the region and/or the country better off.

This leaves the choice between CBA and CGE. It may be a matter of choosing one over the other, or it may be a matter of using both in some way which makes effective use of their different capabilities.

A CBA evaluation is easier to create, but there are several requirements for a CGE evaluation. To start with, there needs to be a suitable model available. With CGE models proliferating in most developed, and many less-developed, countries this is usually not much of a problem. The next question is cost. These days CGE model simulations are cheap once a model is available. There is a cost in terms of labour time in adapting the chosen model to analyse the specific investment evaluation question. There is some cost in terms of the intellectual property of the model when using a research centre or consultant. Finally, there is a question of the degree of disaggregation of the model- many models are quite aggregated, and not capable of handling the detail necessary for accurate analysis. However, detail can be handled by the use 
of sub-models of the chosen model (though there is a cost in terms of about time to develop these sub-models). Just as with CBA, additional detail can be achieved at a cost. However, with medium to large projects, the cost of the evaluation is small compared to the cost of the investment.

CBA is a long-established technique, but the application of CGE models to investment evaluation, and in particular the evaluation of airport investments, is quite new. As a result, there are issues to be used as to how best to use them. Some of these concern how to simulate the investment in the model. Several CGE studies have not used the full potential of the technique. For example, they have concentrated on measuring the more macro impacts, such as those on output and employment, and left the core question of whether the economy is better or worse off as a result of the investment to a CBA study. There is still confusion as to whether a CGE model can assess welfare in the same way as CBA does (it can). CGE models can be used to assess the net social benefits from an investment in the same way that CBA do.

Once the practical problems as discussed above are addressed, there are several ways in which a CGE approach can lead to a more accurate measure of the benefits and costs of an airport project. Some of these are:

1. A CGE approach can evaluate the general equilibrium aspects of an investment, which CBA cannot. These could be significant - we do not know, but we can only find out using a CGE model. This is an important question which needs to be answered;

2. CGE can provide a general equilibrium measure of non-local externalities, such as greenhouse gas emissions, though CBA is limited to a partial equilibrium measure;

3. CGE models can analyse distributional aspects in terms of ultimate incidence of benefits and costs of an investment, which CBA cannot;

4. There are practical evaluation problems which can be handled, at least in part, by a CGE approach, including measuring some of the wider economic benefits (WEBs) of aviation;

5. Widely spread benefits and costs, such as the benefits or costs of tourism, which CBA cannot handle, can be handled with a CGE approach, and

6. CGE models can be used to estimate the effects of an airport on unemployment, though they cannot be used to estimate the benefits of reducing unemployment without further information on shadow wages.

While CBA is a rigorous way of measuring many of the benefits and costs of airport investments, it is incomplete. The CGE approach can give us a more accurate evaluation of the costs and benefits of airport projects, and is thus highly relevant, especially when it comes to the evaluation of larger projects. In practice the economist should avoid EIA and use CBA and CGE as tools to evaluate airport investment rigorously ${ }^{9}$.

\footnotetext{
${ }^{9}$ We like to caution the reader that we have provided evidence that, in general, one of the two rigorous methods should be used for airports and, in general, for transport. We think that the decision between CBA and CGE is less a question of theory (which is more general?), but a practical one.
} 


\section{References}

Abelson, P and ADJ Flowerdew (1972) "Roskill's Successful Recommendation", Journal of the Royal Statistical Society, Series A No 4, 467-510

ACRP (2008) Airport Economic Impact. Methods and Models, Transportation Research Board, Washington

Adams, P, Horridge, J M and Parmenter, B (2000) MMRF-Green: A Dynamic, Multi-Sectoral Multi-Regional Model of Australia, Center of Policy Studies, Monash University, Melbourne

Airports Commission (2014) 2 Economy: Wider Impacts Assessment, London, PwC/ Airports Commission November

Airports Commission (2015a) Airport Commission expert advisor note. A Note from Expert Advisors, Prof. Peter Mackie and Mr Brian Pearce, on key issues considering the Airports Commission Economic Case, London, Airport Commission, May

Airports Commission (2015b) Airport Commission Final Report, London, Airport Commission, July

Australian and NSW Governments (2012) Joint Study on Aviation Capacity in the Sydney Region, report to Australian Government and N.S.W. Government, Canberra and Sydney.

Baum, H., Kurte, J., Esser, K. (2007): Regionalwirtschaftliche Effekte einer Betriebsgenehmigung mit Kernruhezeit für den Airport Berlin Brandenburg International BBI. Köln: IfV/KE-Consult.

Blake, (2009) “The dynamics of tourism's economic impact”, Tourism Economics (2009), 15, $615-628$

Boardman, A. E., Greenberg, D. H., Vining, A. R., \& Weimer, D. L. (2017). Cost-benefit analysis. Cambridge Books.

Brisbane Airport (2007), Volume A: Background and Need, Chap 2 Need for the Project The Environmental Impact Statement (EIS) and Major Development Plan (MDP), by Sinclair Knight Merz, http://www.bne.com.au/corporate/upgrading-your-airport/newparallel-runway/eismdp

Bröcker, J., Korzhenevych, A., and Schürmann, C. (2010), "Assessing spatial equity and efficiency impacts of transport infrastructure projects", Transportation Research Part $B$, doi:10.1016/j.trb.2009.12.008.

Broecker, J and J Mercenier, (2011) "General Equilibrium Models for Transportation Economics", in A de Palma, R. Lindsey, E Quinet and R Vickerman eds, A Handbook of Transport Economics, Edward Elgar, Cheltenham, pp 21-45.

Buckley, P.H. (1992), “A transportation-oriented interregional computable general equilibrium model of the Unite States", The Annals of Regional Science 26, 331-348.

Bulwien, H., R Hujer, S. Kokot,C. Mehlinger, B. Rürup, and T. Voßkamp (1999) Einkommensund Beschäftigungseffekte des Flughafens Frankfurt/Main, Frankfurt. 
Burghouwt, G., \& Redondi, R. (2013) "Connectivity in air transport networks: an assessment of models and applications", Journal of Transport Economics and Policy (JTEP), 47(1), 35-53.

Butler, S. E., \& Kiernan, L. J. (1986). Measuring the Regional Economic Significance of Airports (No. DOT/FAA/PP/87-1). Federal Aviation Adminstration Washington DC Office of Airport Planning and P Programming.

Butler, S. E., \& Kiernan, L. J. (1992) Estimating the regional economic significance of airports (No. DOT/FAA/PP-92-6). United States. Federal Aviation Administration.

Carruthers, R and D Hensher (1976). "Resource Value of Business Air Travel Time", in I Heggie (ed) Modal Choice and the Value of Travel Time, Oxford, Oxford University Press, pp164-185

Central Planning Bureau (1974), Cost-Benefit Analysis Second National Airport, General Report, Den Hague.

Cooper, A. and Smith, P (2005), The Economic Catalytic Effects of Air Transport in Europe, Eurocontrol Brussels.

Czerny, A (2008), „Managing Congested Airports Under Uncertainty“, in Czerny, A., P. Forsyth, D. Gillen, H-M. Niemeier (eds.) Airport Slots. International Experiences and Options for Reform, Ashgate, Farnham, pp111-126

Czerny, A., P. Forsyth, D. Gillen, H-M. Niemeier (eds.) (2008) Airport Slots. International Experiences and Options for Reform, Ashgate, Farnham

De Rus, G. (2010): Introduction to Cost-Benefit Analysis: Looking for Reasonable Shortcuts. Edward Elgar. Cheltenham

Del Bo, C., Fiorio, C., \& Florio, M. (2011) "Shadow wages for the EU regions", Fiscal Studies, 32(1), 109-143.

Dings, J.M.W, R.C.N. Wit, B.A. Leurs, M.D. Davidson (2003) External Costs of Aviation Federal Ministry for the Environment, Nature Conservation and Nuclear Safety Research Report 29996106 UBA-FB 000411, CE, Centre for Energy Conservation and Environmental Technology, Delft

Dixon, (2009) "Comments on the Productivity Commission's Modelling of the Economy-Wide Effects of Future Automotive Assistance” Economic Papers, Vol 28, No 1, 11-18

Dwyer, L., Forsyth, P., Spurr, R., \& Hoque, S. (2013) "Economic impacts of a carbon tax on the Australian tourism industry". Journal of Travel Research, 52(2), 143-155.

Dwyer, L., Forsyth, P., \& Spurr, R. (2006). Assessing the economic impacts of events: A computable general equilibrium approach. Journal of travel research, 45(1), 59-66.

Empirica (1996) Die Bedeutung des Flughafens Hamburg für die Metropolregion, Hamburg: Freie und Hansestadt Hamburg Wirtschaftsbehörde

European Investment Bank (2013) The Economic Appraisal of Investment Projects at the EIB, Luxembourg 
European Commission (2014) Guide to Cost-Benefit Analysis of Investment Projects. Economic appraisal tool for Cohesion Policy 2014-2020. Belgium. European Union.

FAA (1999) Airport benefit-cost analysis guidance, Federal Aviation Administration Washington

Forsyth, P. (1972) “The Timing of Investment in Airport Capacity”, Journal of Transport Economics and Policy, 6, 51-68

Forsyth, P (1980) "The Value of Time in an Economy with Taxation, Journal of Transport Economics and Policy, 337-362

Forsyth, P (2020) "Assessing the Wider Economic Benefits of Air Transport", Transport Policy, forthcoming

Forsyth, P and H-M Niemeier (2008), "Setting Slot Limits at Congested Airports", in Czerny, A., P. Forsyth, D. Gillen, H-M. Niemeier (eds.) Airport Slots. International Experiences and Options for Reform, Ashgate, Farnham, pp63-84

Forsyth, P and L Dwyer, R Spurr and T Pham (2014) “The Impact of Australia's departure tax: Tourism versus the Economy?" Tourism management 40, 126-136

Fritz, O., H. Gassler, K. Nowotny, W. Puwein, F. Steyer, G. Streicher (2007) Wirtschaftsfaktor Flughafen Wien. Eine Analyse der Regionalwirtschaftlichen Auswirkungen im Auftrag der Flughafen Wien Aktiengesellschaft, Wien

Grady, P. and R. A. Muller (1986) "On The Use and Misuse of Input-Output Based Impact Analysis in Evaluation”, MPRA Paper No. 22063. http://mpra.ub.unimuenchen.de/22063/

Graham, D. J. (2007) “Agglomeration, productivity and transport investment". Journal of Transport Economics and Policy, 41, 317-343.

Hakfoort, J. Poot, T and Rietveld, P. (2001) "The Regional Economic Impact of an Airport: The Case of Amsterdam Schiphol Airport”, Regional Studies, 35, 595-604

Hujer, R., \& Kokot, S. (2001) Frankfurt Airport Impact in Regional and National Employment and Income in: W. Pfähler (ed.), Regional Input-Output Analysis, Baden-Baden, Nomos, pp. 111-155

InterVISTAS (2006) Measuring the Economic Rate of Return on Investment in Aviation, InterVISTAS, Vancouver

InterVISTAS (2015) Economic Impact of European Airports. A Critical Catalyst to Economic Growth, prepared for ACI Europe, Brussels

Jorge-Calderón, D. (2014). Aviation investment: economic appraisal for airports, air traffic management, airlines and aeronautics. Ashgate: Farnham.

Krugmann, P. (1991) Geography and Trade, MIT Press: Cambridge, Mass.

Leontief, W. (1987) Input-output analysis. The New Palgrave. A dictionary of economics, 2(1), 860-64 
Levine, M. E. (1969) "Landing fees and the Airport Congestion Problem", Journal of Law and Economics, 12, 79-109

Little, I and J Mirrlees (1968) Manual of Industrial Project Analysis Vol 2, Paris, OECD Development Center

Little, I and J Mirrlees (1974) Project Appraisal and Planning for Developing Countries, New York, Basic Books

Lublinski, A. E. (2001) Identifying geographical business clusters-A critical review and classification of methods using I/O data. in W. Pfähler (ed.), Regional Input-Output Analysis, Baden-Baden, Nomos, pp. 223-246.

Madden, J.R. (2004), Assessing the regional economic impact of an airport: a dynamic multiregional CGE study of Melbourne airport. Draft Paper presented to Fourth Biennial Regional CGE Modelling Workshop, Melbourne, 16 \& 17 September2004, viewed September 2013, available at http://www.monash.edu.au/policy/regional/maddpap.pdf>

Malina, R., Wollersheim, C. (2007) Measuring the regional economic impact of airports: a comparative analysis of different methodological approaches, Proceedings of the 11th Annual World Conference of the Air Transport Research Society, Berkeley, USA., June 21-24 2007

Marshall, A. (1920) Principles of Economics, $8^{\text {th }}$ edition, London

Melbourne Airport (2003), Melbourne Airport Economic Impact Study, Sinclair Knight Merz, Melbourne

Mills, G. (1982) "Investment in Airport Capacity - A Critical Review of the MANS, (Major Airport Needs of Sydney) Study, Working Papers 55, University of Sydney, School of Economics

Mishan, E.J. (1970), “What is wrong with Roskill?”, Journal of Transport Economics and Policy, 4,.221-34

Mohring, H (1976) "Optimisation and Scale Economies in Urban Bus Transportation", American Economic Review, 62, 591-604

Mukkala, K., \& Tervo, H. (2013). Air transportation and regional growth: which way does the causality run?. Environment and Planning A, 45, 1508-1520.

Niemeier, H.-M. (2001) "On the use and abuse of Impact Analysis for airports: A critical view from the perspective of regional policy," in: W. Pfähler (ed.), Regional Input-Output Analysis, Baden-Baden, Nomos 2001, pp. 201-220

Njoya, E. T. (2020). An analysis of the tourism and wider economic impacts of price-reducing reforms in air transport services in Egypt. Research in Transportation Economics, $79(\mathrm{C})$.

NSW Business Chamber (2013). Economic Impact of a Western Sydney Airport. Report prepared by Deloitte Access Economics for the NSW Business Chamber. 
https://www.thechamber.com.au/thechamber.com.au/media/DefaultImages/Economic-Impact-of-a-Western-Sydney-Airport.pdf

Nwaneri, V. (1970), Equity in cost-benefit analysis: A case study of the third London airport. Journal of Transport Economics and Policy, 4, 235-245.

Ody, J.G. (1969), Application of Cost Benefit Analysis to Airports - The case of Nicosia. London: London School of Economics and Political Science.

Partidário, M. R., \& Coutinho, M. (2011)“The Lisbon new international airport: The story of a decision-making process and the role of Strategic Environmental Assessment", Environmental Impact Assessment Review, 31(3), 360-367.

Paul, M. (1971) "Can Aircraft Noise Nuisance be Measured in Money?", Oxford Economic Papers, 23, 297-322

Pearce, B. (2013) "Wider Economic Benefits: An Industry Perspective”, Presentation at GARS Workshop, July

Pfähler, W. (2001) “Input-Output Analysis: A user's guide and call for standardization”, in: W. Pfähler (ed), Regional Input-Output Analysis, Baden-Baden, Nomos, pp. 11- 46

PwC, (2013) The Economic Impact of Air Passenger Duty [online]. London: PricewaterhouseCoopers LLP

Quinet, E. (2000) "Evaluation Methodologies of Transportation Projects in France". Transport Policy, 7, 27-34.

Ray, A (1984) Cost-Benefit Analysis Issues and Methodologies, World Bank, Johns Hopkins University Press, Baltimore and London

Roskill, E. (1971) Commission on the Third London Airport: Report. HM Stationery Office.

Thießen, F (2009) "Die Bedeutung von Flughäfen für die regionale Wirtschaft", in: HeinrichBöll-Stiftung, Kommunalpolitische Infothek Thema: Regionale Flughäfen, in: http://www.kommunale-info.de/, 2009, URL des Beitrages: www.kommunaleinfo.de/asp/search.asp? ID=3661

Tscharaktschiew, S., \& Hirte, G. (2012). Should subsidies to urban passenger transport be increased? A spatial CGE analysis for a German metropolitan area. Transportation Research Part A: Policy and Practice, 46(2), 285-309.

Ueda, Takayuki, A. Koike, K. Tsuchiya and K. Yamaguchi (2005), "Spatial Benefit Incidence Analysis of Airport Capacity Expansion: Application of SCGE Model to the Haneda Project in Global Competition in Transportation Markets:" Analysis and Policy Making, Research in Transportation Economics Vol. 13, Elsevier.

Venables, A. J. (2007) "Evaluating Urban Transport Improvements," "Cost-Benefit Analysis in the Presence of Agglomeration and Income Taxation", Journal of Transport Economics and Policy, 41, 173-188. 
Vickerman, R (2013) "The Wider Economic Impacts of Mega Projects in Transport", in H Priemus and B van Wee (eds) International Handbook on Mega-Projects, Cheltenham, Edward Elgar, 381-398.

Waters, W.G. (1976) "Impact Studies and the Evaluation of Public Projects", Annals of Regional Science, 10, 98-103. 
Appendix

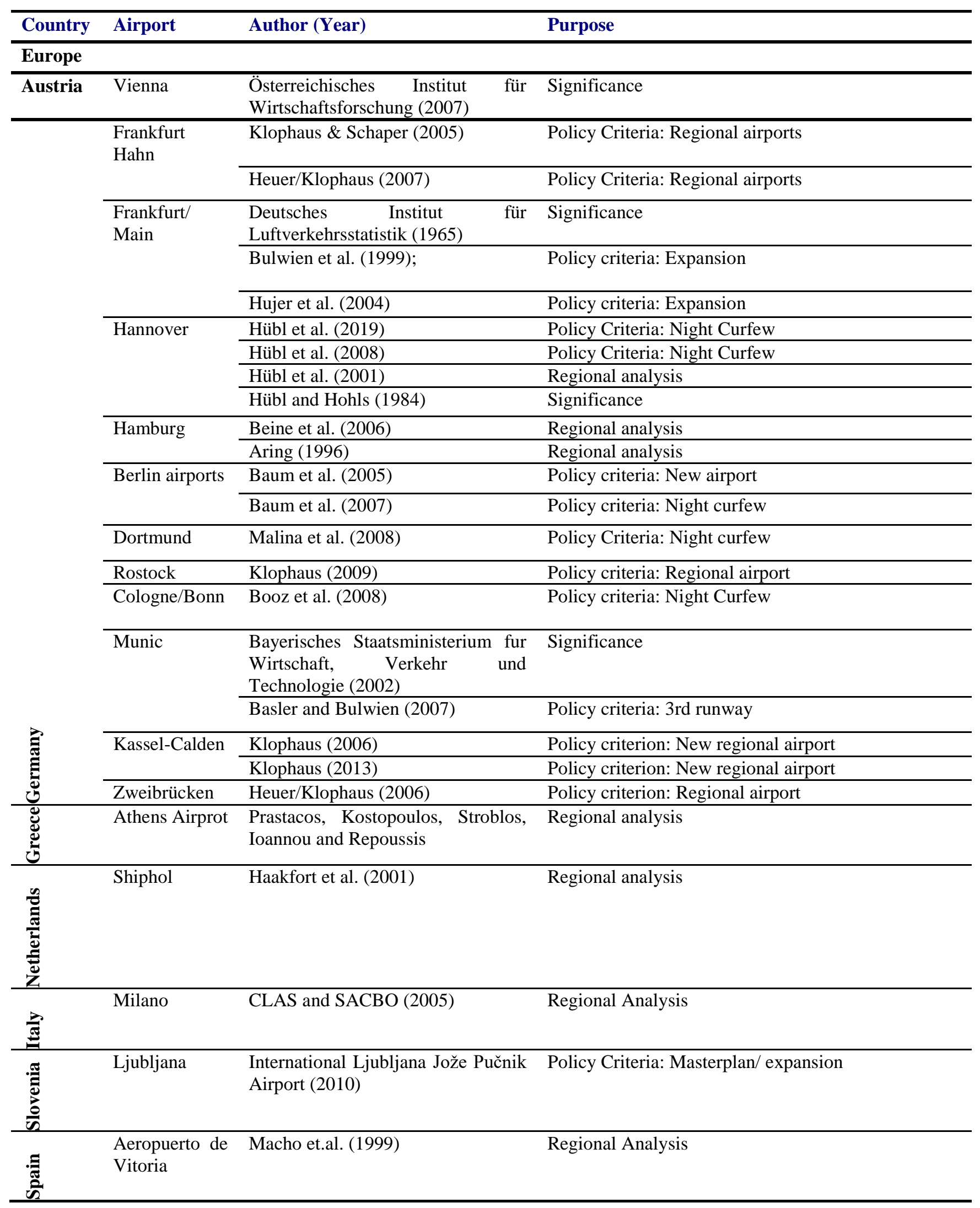




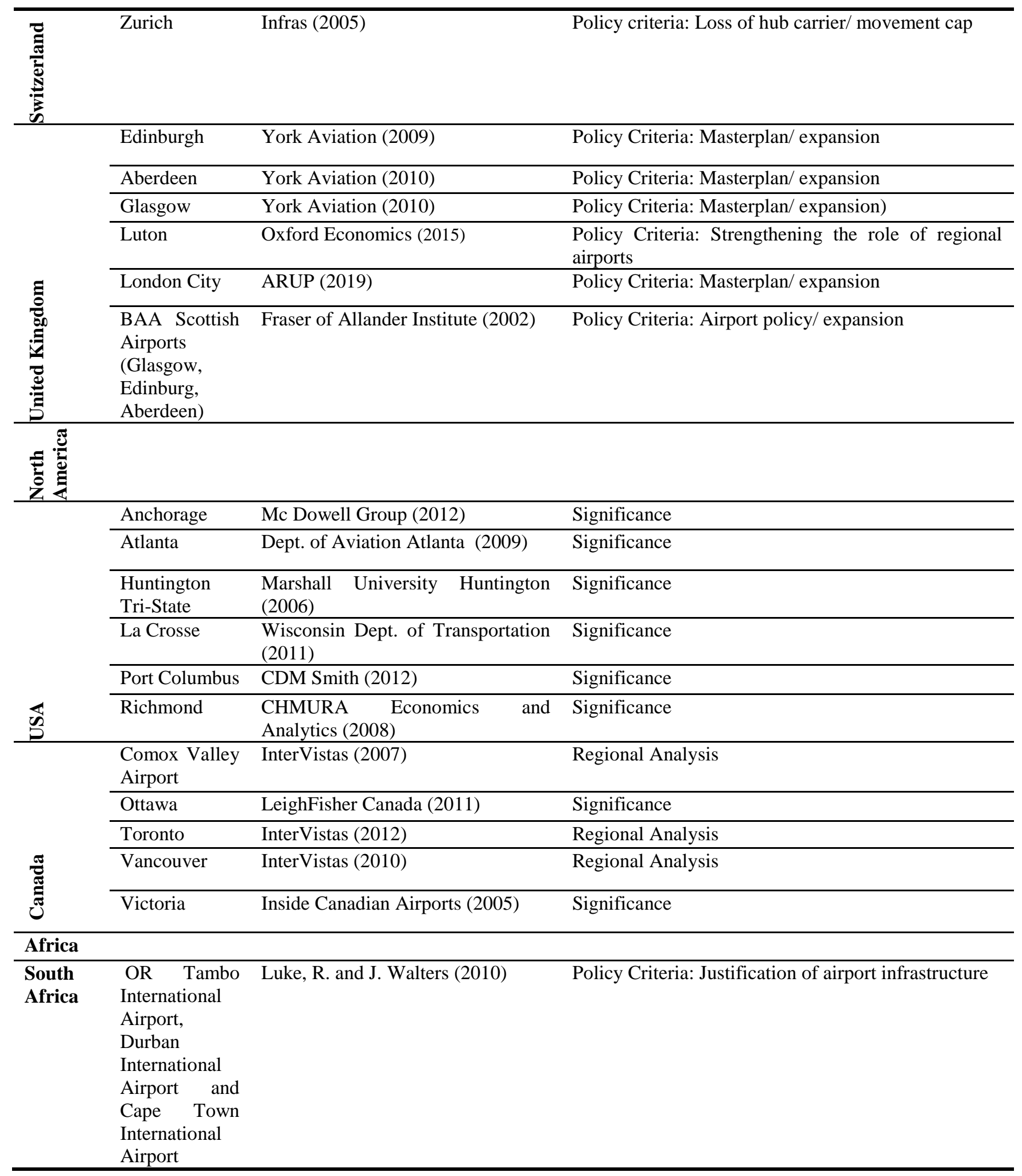

